\title{
ANALISIS DAYA DUKUNG DAN DAYA TAMPUNG LAHAN PERMUKIMAN KOTA DENPASAR
}

\author{
I Kadek Fajar Arcana ${ }^{1 * 1}$, Syamsul Alam Paturusi ${ }^{2}$, I Wayan Suarna ${ }^{3}$ \\ ${ }^{1)}$ Dinas Pekerjaan Umum, Penataan Ruang, Perumahan dan Kawasan Permukiman Provinsi Bali \\ ${ }^{2}$ Program Studi Arsitektur, Fakultas Teknik, Universitas Udayana \\ ${ }^{3)}$ Program Studi Peternakan, Fakultas Peternakan, Universitas Udayana
}

*Email: kadekfajararcana@gmail.com

\section{ABSTRACT}

\section{ANALYSIS OF THE SUPPORTING CAPACITY AND SUPPLY CAPABILITY OF RESIDENTIAL LAND IN DENPASAR CITY}

Denpasar City is the capital city of Bali Province which has a rapid population growth rate every year. Along with the rapid population growth, this has an impact on meeting the needs of housing and other regional service facilities. The increasing number of population automatically causes an increase in the need for housing. Analysis of residential land supporting capacity and supply capability needed to preserve the environment. This research was conducted with a quantitative approach which describes and describes the results in the form of numbers or nominal values by explaining clearly either with the help of pictures, tables, or graphs. The quantitative data described are the population, land area and land capability area to support and accommodate housing as a place to live in Denpasar City. Based on the results of the analysis using the overlapping method and scoring using a GIS application. Denpasar City potential land to be developed as a residential area after being adjusted to the settlement plan in the Denpasar City Spatial Plan is available for 454,73 hectares of the total area of Denpasar City of 12,521 hectares or about $3.63 \%$ of land in Denpasar city. The capacity of Denpasar City houses is able to accommodate around 44.736 housing units and 178.943 residents. There are 2 sub-districts that are not able to accommodate the population in 2030, namely South Denpasar and North Denpasar. However, cumulatively, Denpasar City is still able to accommodate population growth in 2030 in obtaining residential land.

Keywords: Supporting Capacity and Supply Capability; Residential Land; Denpasar City.

\section{PENDAHULUAN}

Kota Denpasar adalah Ibukota Provinsi Bali memiliki laju pertumbuhan penduduk yang pesat tiap tahun. Jumlah penduduk di Kota Denpasar mengalami pertumbuhan seiring berjalannya waktu. Dampak dari pertumbuhan penduduk yang begitu pesat berpengaruh terhadap kebutuhan hunian dan fasilitas pelayanan wilayah lainnya. Penggunaan lahan Kota Denpasar yang terus berubah disebabkan karena adanya pemenuhan kebutuhan terhadap lahan dari perkembangan jumlah penduduk. Ketersediaan lahan yang tidak mampu mengimbangin pemenuhan kebutuhan perumahan, perkantoran, dan lain sebagainya menyebabkan terjadinya perubahan pemanfaatan lahan pertanian menjadi area terbangun.

Data Badan Pusat Statistik (BPS) Kota Denpasar, jumlah penduduk pada tahun 2010 adalah 793.000 jiwa, sedangkan pada 2018 penduduk Kota Denpasar meningkat menjadi 930.600 jiwa atau meningkat sebesar $17,35 \%$. Berdasarkan dari data tersebut, dalam delapan tahun terakhir dari tahun 2010 hingga tahun 2018 pertambahan penduduk di Kota Denpasar sebanyak 137.600 jiwa atau jika dirata-ratakan setiap tahun penduduk Denpasar bertambah sebanyak 17.200 jiwa. Dengan adanya pertumbuhan penduduk ini maka jumlah kebutuhan (demand) akan lahan hunian semakin bertambah sedangkan ketersedian lahan (supply) di Kota Denpasar tidak dapat dikembangkan lagi.

Dengan adanya pertumbuhan penduduk sebesar $17,35 \%$ selama 8 tahun terakhir di Kota Denpasar, akan terus membutuhkan lahan baru untuk pengembangan permukiman kedepannya, tetapi ketersediaan lahan terbatas. Meningkatnya pertumbuhan penduduk juga berpengaruh terhadap penurunan kualitas lingkungan karena pemanfaatan lahan yang berlebihan. Menurut Wiryananda, et al. (2018) "perubahan alih fungsi lahan di Kota Denpasar selama lima tahun terakhir dari tahun 2011 hingga tahun 2015 banyak ruang terbuka hijau yang telah beralih fungsi menjadi kawasan permukiman akibat bertambahnya populasi yang begitu cepat." Penurunan ruang terbuka hijau (RTH) selama lima tahun terakhir sebesar 21,888 ha, penurunan RTH disebabkan paling banyak oleh kebutuhan akan rumah tinggal sehingga banyak penurunan kualitas lingkungan yang disebabkan oleh alih fungsi lahan yang berlebihan. Untuk bisa mempertahankan 
ketersediaan RTH sebesar $35 \%$ dari total luas wilayah serta sebagai evaluasi dari Rencana Tata Ruang Wilayah (RTRW), kajian terhadap daya dukung dan daya tampung lahan permukiman bisa dijadikan acuan sehingga ruang kota yang aman, dan nyaman dapat diwujudkan.

Undang-Undang Nomor 32 tahun 2009 tentang Perlindungan dan Pengelolaan Lingkungan Hidup menyebutkan daya dukung dan daya tampung lingkungan hidup sangat diperlukan untuk menjaga keberlangsungan lingkungan serta menjaga kehidupan didalamnya. Kajian tentang daya dukung dan daya tampung lahan permukiman diperlukan untuk menjaga kelestarian lingkungan, baik berupa penggunaan lahan maupun sumber daya alam di sekitarnya. Penelitian ini bertujuan untuk mencari kemampuan daya dukung dan daya tampung lahan permukiman Kota Denpasar terhadap pemenuhan kebutuhan lahan dari pertumbuhan penduduk selama 10 tahun kedepan.

\section{METODOLOGI}

Metode penelitian menggunakan pendekatan kuantitatif dimana menjabarkan dan menggambarkan hasil berupa angka-angka atau nominal dengan memaparkan dengan jelas baik dengan bantuan gambar, tabel, maupun grafik. Data kuantitatif yang dijabarkan adalah jumlah penduduk, luas lahan dan luas kemampuan lahan untuk mendukung dan menampung perumahan sebagai tempat hunian di Kota Denpasar.

Metode penelitian deskriptif kuantitatif adalah mendeskripsikan data kuatitatif berupa menjabarkan atau menjelaskan hasil dari penelitian dengan menggunakan angka yang menggambarkan karakteristik subjek penelitian yang kemudian dijelaskan dengan bahasa yang sederhana dibantu dengan penambahan tabel, diagram dan grafik untuk mempermudah dipahami. Penelitian dilakukan menganalisa daya dukung dan daya tampung setiap kecamatan terlebih dahulu, kemudian digabung serta direratakan menjadi hasil dari kemampuan daya dukung dan daya tampung Kota Denpasar.

\subsection{Waktu dan Lokasi Penelitian}

Penelitian ini dimulai pada awal tahun 2021 dimana proyeksi kependudukan dan daya dukung daya tampung lahan permukiman diproyeksikan selama 10 tahun kedepan.

Lokasi penelitan dilakukan di Kota Denpasar, terletak di 08 14'17"-08 50'57" LS dan $115^{\circ} 05^{\prime} 02^{\prime \prime}-115^{\circ} 15^{\prime} 09^{\prime \prime}$ BT. Luas Kota Denpasar sekitar 12,521 ha atau 2,27 \% keseluruhan luas Provinsi Bali. Kota Denpasar terdiri dari 4 wilayah Kecamatan, 27 Desa dan 16 Kelurahan (Gambar 1).

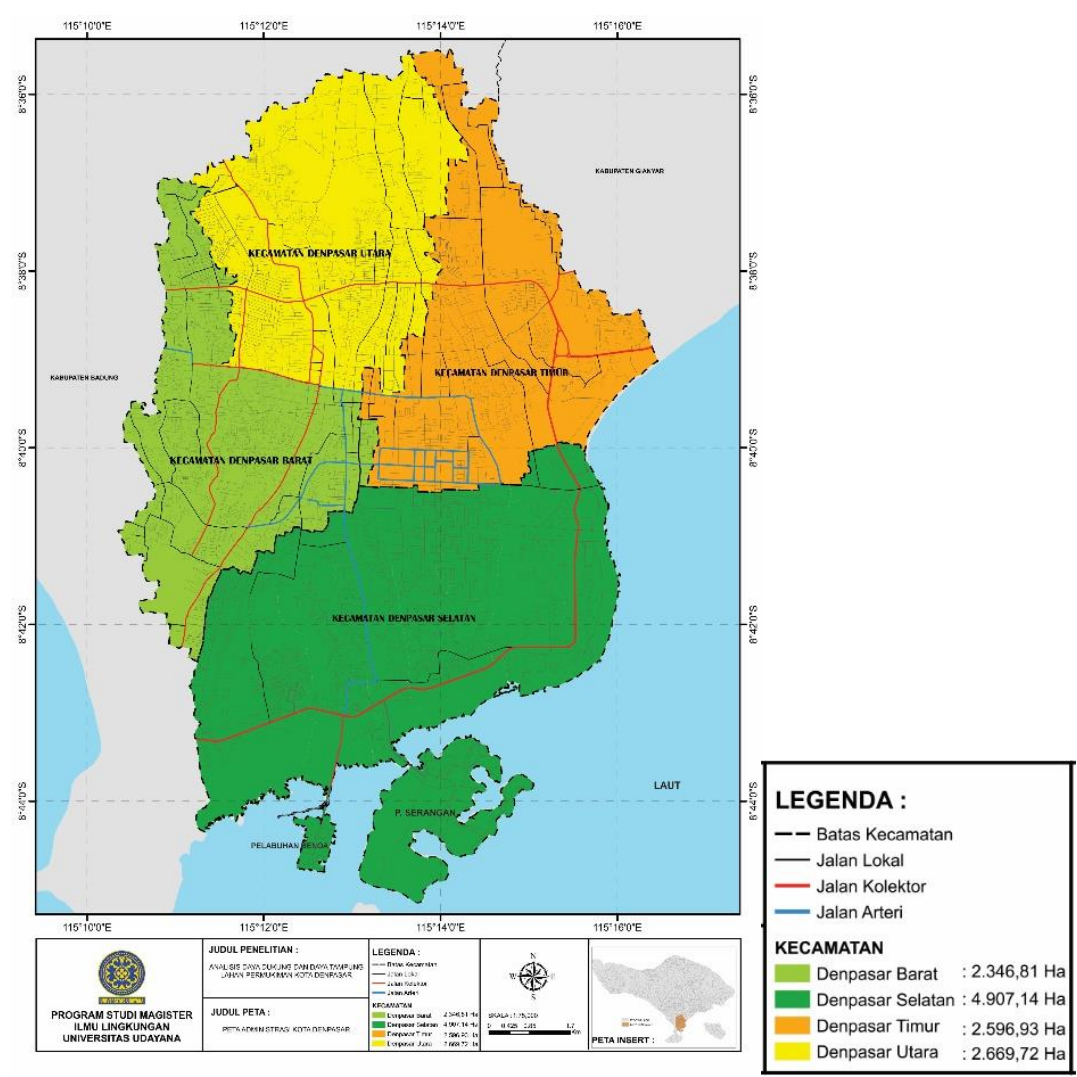

Gambar 1.

Peta Lokasi Penelitian

Sumber: RTRW Kota Denpasar

\subsection{Analisa Data}

Analisa data dilakukan setelah data primer dan sekunder diperoleh. Teknik Analisa dilakukan dalam beberapa tahap. Analisa pertama adalah Analisa kependudukan yang dimana melakukan proyeksi pertumbuhan penduduk dalam 10 tahun mendatang. Kemudian analisa daya dukung lahan menggunakan teknik overlay peta dengan 
pembobotan dan skoring menggunakan aplikasi GIS. Lebih jelasnya dijabarkan sebagai berikut:

\subsubsection{Analisa Pertumbuhan Penduduk}

Metode aritmatik digunakan dalam analisa proyeksi kependudukan, dengan metode ini diasumsikan jumlah penduduk setiap tahun terus mengalami partumbuhan. Rumus proyeksi penduduk dengan metode aritmatik :

$\mathrm{Pt}=\mathrm{Po}+(1+\mathrm{rt}) \quad$ dimana $\quad \mathrm{r}=\frac{\mathbf{1}}{\boldsymbol{t}}\left(\frac{\boldsymbol{P t}}{\boldsymbol{P o}}-\mathbf{1}\right)$

keterangan:

$\mathrm{Pt}=$ penduduk tahun $\mathrm{t}$

Po = jumlah penduduk pada tahun awal

$\mathrm{r}=$ laju pertumbuhan penduduk

$\mathrm{t}=$ periode waktu antara tahun awal dan tahun $\mathrm{t}$

\subsubsection{Analisa Daya Dukung Lahan Permukiman}

Analisa daya dukung lahan permukiman menggunakan metode overlay (tumpang susun) dengan pembobotan dan skoring berdasarkan variabel daya dukung lingkungan. Adapun variabel daya dukung lingkungan untuk lahan permukiman yang dijadikan dasar pemberian skor dapat dilihat pada Tabel 1.

Tabel 1. Variabel Daya Dukung Lahan Permukiman

\begin{tabular}{cc}
\hline No & Variabel \\
\hline 1 & Kemiringan Lereng \\
2 & Jenis Batuan \\
3 & Jenis Tanah \\
4 & Air Tanah \\
5 & Rawan Bencana \\
\hline
\end{tabular}

Sumber : Fansuri, 2017

Peta dari masing-masing variabel diberikan skor dan ditumpang susunkan. Hasil dari tumpang susun peta dari setiap variabel kemudian dibagi sesuai dengan kelas daya dukung lahan. Hasil dari tumpang susun dan skoring setiap variabel kemudian dijadikan peta daya dukung lahan berdasarkan kelayakan membangun pondasi rumah. Kesesuaian lahan potensial pengembangan permukiman diperoleh dengan cara tumpang susun peta daya dukung lahan, peta penggunaan lahan eksisting dan peta rencana permukiman dalam RTRW Kota Denpasar, dapat dilihat pada Gambar 2.

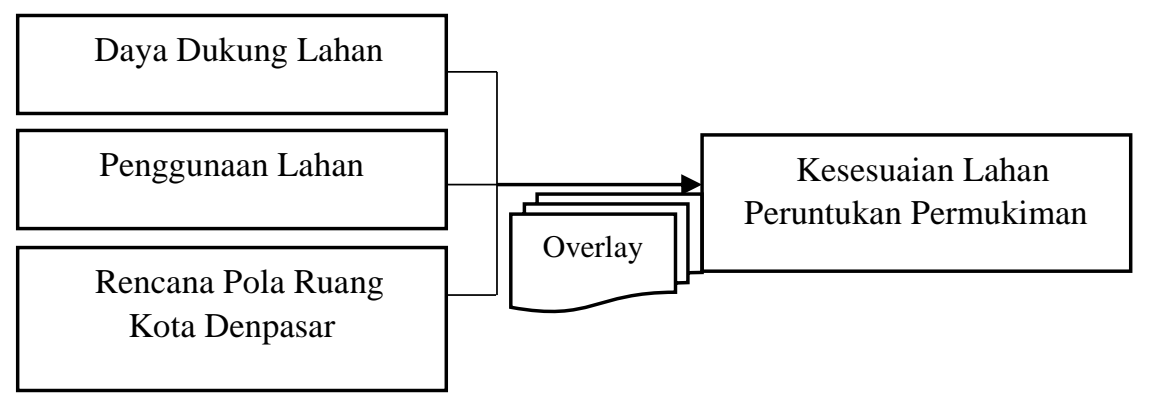

Gambar 2.

Alur Analisa Kesesuaian Lahan Peruntukan Permukiman

\subsubsection{Analisa Daya Tampung Lahan Permukiman}

Adanya pertumbuhan penduduk di setiap wilayah akan berkaitan dengan kemampuan daya tampung lahan dan banyaknya penduduk yang mampu ditampung oleh luasan lahan yang tersedia. Hasil dari analisa daya dukung lahan dan proyeksi penduduk kemudian digunakan untuk menganalisa wilayah yang masih dapat dikembangakn untuk kawasan permukiman dan wilayah mana saja yang tidak dapat dikembangkan, asumsi pemanfaatan ruang untuk penduduk berdasarkan pedoman Rencana Pembangunan dan Pengembangan Perumahan dan Permukiman di Daerah sebagai berikut:

- $70 \%$ diperuntukan untuk perumahan (dengan 30\% untuk PSU) dari luas lahan

- 1 Keluarga terdiri dari 4 orang

Untuk mengetahui kemampuan daya dukung lahan terhadap penduduk digunakan rumus sebagai berikut:

Daya tampung lahan $=$

$70 \%$ x daya dukung lahan potensial $(\mathrm{Ha}) \mathrm{x}$ proporsi hunian $x$ jiwa
Jumlah dan tipe rumah berdasarkan kenetutan hunia berimbangdengan perbandingan $3: 2: 1$ yang asumsinya kavling rumah sederhana : menengah : mewah. Luasan kavling berdasarkan Keputusan Menteri Prasarana Wilayah Nomor 403 tahun 2002 maka perkiraan tipe rumah adalah sebagai berikut:

1. Kavling Rumah Sederhana $=72 \mathrm{~m}^{2}$

2. Kavling Rumah Menengah $=144 \mathrm{~m}^{2}$

3. Kavling Rumah Mewah $=288 \mathrm{~m}^{2}$

\section{HASIL DAN PEMBAHASAN}

\subsection{Kondisi Fisik Kawasan}

Secara geografis, Kota Denpasar terletak pada $08^{\circ} 14^{\prime} 17^{\prime \prime}-08^{\circ} 50^{\prime} 57^{\prime \prime}$ LS dan $115^{\circ} 05^{\prime} 02^{\prime \prime}-$ $115^{\circ} 15^{\prime} 09^{\prime \prime}$ BT. Luas Kota Denpasar sekitar 12.521 ha atau 2,27 \% dari keseluruhan luas Provinsi Bali dapat dilihat pada Tabel 2 . Terdapat 4 kecamatan di Kota Denpasar, dengan 27 desa dan 16 kelurahan. Batas administrasi Kota Denpasar antara lain:

- Utara: Kab. Badung (Kec. Mengwi dan Abiansemal) 
- Selatan: Kab. Badung (Kec. Kuta Selatan) dan Teluk Benoa

- Timur: Kab. Gianyar (Kec. Sukawati) dan Selat Badung

- Barat: Kab. Badung (Kec. Kuta Utara dan Kuta)

Tabel 2. Luas Wilayah Kota Denpasar

\begin{tabular}{llc}
\hline No & Kecamatan & $\begin{array}{c}\text { Luas Wilayah } \\
\text { (ha) }\end{array}$ \\
\hline 1 & Denpasar Selatan & 4.907 \\
2 & Denpasar Utara & 2.670 \\
3 & Denpasar Barat & 2.347 \\
4 & Denpasar Timur & 2.597 \\
& Kota Denpasar & $\mathbf{1 2 . 5 2 1}$ \\
\hline
\end{tabular}

Sumber : hasil olahan RTRW Kota Denpasar

Pada tahun 2010, penduduk Kota Denpasar sebanyak 793.000 jiwa, sedangkan pada tahun 2019 meningkat pesat menjadi 947.100 jiwa. Lebih jelasnya jumlah penduduk Kota Denpasar dapat dilihat pada Tabel 3.

Pada Kota Denpasar, seluruh wilayah memiliki kemiringan diantara 0-8\%. Hampir diseluruh kecamatan memiliki kemiringan yang sama. Dalam kriteria daya dukung lahan permukiman, kemiringan lereng tersebut termasuk kategori datar-landai, dimana dengan kondisi kemiringan tersebut sangat baik untuk dijadikan lokasi untuk mendirikan bangunan ataupun mengembangkan permukiman

Jenis batuan yang menyusun wilayah Kota Denpasar terdiri dari batuan alluvial dan batuan tufa dan endapan lahar Buyan-Beratan dan Batur. Jenis batuan alluvial merupakan jenis batuan yang memiliki tekstur yang pejal dan tergolong berpasir yang tergolong lunak. Sedangkan jenis batuan tufa dan endapan lahar Buyan-Beratan dan Batur merupakan tekstur batuan yang keras sehingga sangat cocok mendirikan pondasi untuk membangun rumah.

Berdasarkan hasil analisis dengan menggunakan data dari RTRW Kota Denpasar, jenis tanah yang menyusun daratan wilayah Kota Denpasar terdiri dari 2 jenis yaitu tanah jenis latosol dan regosol. Tanah latosol merupakan tanah yang mempunyai lapisan solum di dalamnya. Tanahnya berwarna coklat dan memiliki tekstur liat. Tanah regosol adalah tanah yang berasal dari material erupsi gunung berapi yang berupa butiran kasar. Gerakan tanah di wilayah Kota Denpasar berdasarkan data RTRWK, terdiri dari 3 kategori yaitu potensi Gerakan tinggi, menengah dan rendah. Data gerakan tanah didapat dari data potensi gempa yang kemudian diolah. Berikut klasifikasi gerakan tanah yang ada di Kota Denpasar.

Wilayah Kota Denpasar sebagian merupakan kawasan pesisir, terutama Kecamatan Denpasar selatan dan Denpasar timur yang memiliki kawasan pantai sehingga memiliki potensi besar terkena bencana tsunami. Potensi bencana tsunami Kota Denpasar dapat dikategorikan menjadi 4 yaitu potensi tinggi, potensi menengah, potensi rendah, dan zona aman dari bencana tsunami.

Tabel 3. Jumlah Penduduk Kota Denpasar

\begin{tabular}{|c|c|c|c|c|c|}
\hline \multirow{2}{*}{ Kecamatan } & \multirow{2}{*}{ Luas (ha) } & \multicolumn{2}{|c|}{ Jumlah Penduduk (jiwa) } & \multirow{2}{*}{$\begin{array}{c}\text { Kepadatan } \\
\text { Penduduk } \\
\text { Tahun 2019 } \\
\text { (jiwa/ha) } \\
\end{array}$} & \multirow{2}{*}{$\begin{array}{c}\text { Laju } \\
\text { Pertumbuhan } \\
\text { Penduduk }\end{array}$} \\
\hline & & 2010 & 2019 & & \\
\hline Denpasar Selatan & 4.907 & 246.310 & 305.400 & 62 & 23,99 \\
\hline Denpasar Utara & 2.670 & 176.840 & 207.900 & 78 & 17,56 \\
\hline Denpasar Barat & 2.347 & 230.720 & 273.600 & 117 & 18,59 \\
\hline Denpasar Timur & 2.597 & 139.130 & 160.200 & 62 & 15,14 \\
\hline Kota Denpasar & $12.521^{\top}$ & $793.000^{\top}$ & 947.100 & 76 & 19,43 \\
\hline
\end{tabular}

Sumber : hasil olahan data BPS Kota Denpasar 2020

\subsection{Proyeksi Kependudukan}

Analisa kependudukan berupa proyeksi jumlah penduduk bukan merupakan perhitungan dan ramalan banyaknya penduduk di masa depan, akan tetapi perhitungan yang dilakukan secara ilmiah yang menggunakan komponen perhitungan seperti laju jumlah penduduk. Proyeksi jumlah penduduk nantinya akan dipergunakan untuk mengetahui banyaknya penduduk yang mampu ditampung oleh lahan yang tersedia sebagai tempat untuk bermukim. Proyeksi penduduk Kota Denpasar dapat dilihat pada Tabel 4.
Tabel 4. Proyeksi Penduduk Kota Denpasar

\begin{tabular}{l|rrr|}
\hline \multirow{2}{*}{ Kecamatan } & \multirow{2}{*}{$\begin{array}{c}\text { Jumlah Penduduk } \\
\text { Tahun 2019 }\end{array}$} & \multicolumn{2}{c}{$\begin{array}{c}\text { Proyeksi Jumlah } \\
\text { Penduduk }\end{array}$} \\
\cline { 3 - 5 } & & $\mathbf{2 0 2 5}$ & \multicolumn{1}{c|}{$\mathbf{2 0 3 0}$} \\
\hline Denpasar Selatan & 305.400 & 346.934 & 377.169 \\
\hline Denpasar Utara & 207.900 & 236.174 & 256.757 \\
\hline Denpasar Barat & 273.600 & 310.810 & 337.896 \\
\hline Denpasar Timur & 160.200 & 181.987 & 197.847 \\
\hline Kota Denpasar & $\mathbf{9 4 7 . 1 0 0}$ & $\mathbf{1 . 0 7 5 . 9 0 6}$ & $\mathbf{1 . 1 6 9 . 6 6 9}$ \\
\hline Sumber $:$ analisis 2021 & & &
\end{tabular}

Dalam Departemen Kimpraswil tahun

2003, jenis kota berdasakan jumlah penduduk antara digolongkan menjadi :

- penduduk sekitar 10.000 - 100.000 Jiwa merupakan Kota Kecil

- penduduk sekitar 100.000 - 500.000 Jiwa merupakan Kota Sedang

- penduduk sekitar 500.000 - 1.000.000 Jiwa merupakan Kota Besar 
- penduduk sekitar $1.000 .000-8.000 .000$ Jiwa merupakan Kota Metropolitan

- penduduk lebih dari 8.000.000 Jiwa merupakan Kota Mega politan

Berdasarkan pedoman Kimpraswil 2003, pada tahun 2019 Kota Denpasar termasuk kota besar, akan tetapi dengan proyeksi penduduk pada tahun 2030 Kota Denpasar menjadi Kota
Metropolitan dengan jumlah penduduk sebesar 1.169.699 jiwa. Pertumbuhan penduduk dari tahun 2019 sampai 2030 diproyeksikan bertambah sebesar 222.562 jiwa. Perhitungan kepadatan penduduk didapat dari jumlah penduduk dibagi luas wilayah. Kepadatan penduduk Kota Denpasar dapat dilihat pada Tabel 5.

Tabel 5. Kepadatan Penduduk Kota Denpasar

\begin{tabular}{|c|c|c|c|c|c|}
\hline No. & Kecamatan & $\begin{array}{l}\text { Luas Wilayah } \\
\text { (ha) }\end{array}$ & $\begin{array}{l}\text { Jumlah Penduduk } \\
\text { Tahun } 2030\end{array}$ & $\begin{array}{l}\text { Kepadatan Penduduk } \\
\text { Tahun } 2030 \text { (jiwa/ha) }\end{array}$ & Klasifikasi \\
\hline 1 & Denpasar Selatan & 4.907 & 377.169 & 77 & Rendah \\
\hline 2 & Denpasar Utara & 2.670 & 256.757 & 96 & Rendah \\
\hline 3 & Denpasar Barat & 2.347 & 337.896 & 144 & Rendah \\
\hline \multirow[t]{2}{*}{4} & Denpas ar Timur & 2.597 & 197.847 & 76 & Rendah \\
\hline & Kota Denpas ar & 12.521 & 1.169 .669 & 93 & Rendah \\
\hline
\end{tabular}

Sumber : analisis 2021

Berdasarkan Tabel 5 kepadatan penduduk Kota Denpasar tergolong rendah berdasarkan klasifikasi dari Standar Nasional Indonesia Nomor 03-1733-2004 tentang Tata Cara Perencanaan Lingkungan Perumahan. Meskipun Kota Denpasar diperkirakan menjadi kota metropolitan pada tahun 2030 berdasarkan proyeksi pertumbuhan penduduk, akan tetapi kepadatan penduduk Kota Denpasar masih tergolong kategori rendah dengan kepadatan 93 jiwa/ha.

\subsection{Daya Dukung Lahan Permukiman}

Analisis daya dukung lahan permukiman Kota Denpasar diwali dengan melakukan tumpang susun peta kemampuan lahan berdasarkan tentang Kriteria Daya Dukung Lahan Permukiman di kawasan perkotaan yang kemudian diberi bobot sehingga setiap variabel memiliki skor. Setelah memiliki skor kemudian dicari interval kemampuan lahan dan disandingkan dengan penggunaan lahan eksisting dan kebijakan terkait pengembangan permukiman dalam RTRW Kota Denpasar.

Penggunaan lahan Kota Denpasar sangat bervariasi, mulai dari peruntukannya. Penggunaan lahan Kota Denpasar dapat digolongkan menjadi 2 yaitu lahan yang sudah terbangun dan non terbangun. Penggunaan lahan yang sudah terbangun merupakan area atau wilayah yang sudah dimanfaatkan dan didirikan bangunan atau sarana untuk pemenuhan kebutuhan hidup, diantaranya seperti permukiman, perkantoran, industri, sarana pariwisata dan lain sebagainya. Sedangkan penggunaan lahan non terbangun adalah wilayah yang sudah atau belum termanfaatkan dan belum didirikan bangunan, diantaranya seperti hutan mangrove, ruang terbuka hijau (RTH), lahan pertanian dan perkebunan serta fasilitas olahraga/lapangan. Jenis penggunaan lahan Kota Denpasar dapat dilihat pada Tabel 6 .

Tabel 6. Jenis Penggunaan Lahan Kota Denpasar

\begin{tabular}{|c|c|c|c|}
\hline $\begin{array}{c}\text { Kategori } \\
\text { Penggunaan } \\
\text { Lahan } \\
\end{array}$ & Penggunaan Lahan & Luas (ha) & $\%$ \\
\hline \multirow{10}{*}{ Terbangun } & Permukiman & 5.771 & 46,09 \\
\hline & Perkantoran dan Perekonomian & 756 & 6,04 \\
\hline & Fasilitas Kesehatan & 31 & 0,25 \\
\hline & Fasilitas Pendidikan & 122 & 0,97 \\
\hline & Fasilitas Peribadatan & 35 & 0,28 \\
\hline & Fasilitas Sosial & 22 & 0,18 \\
\hline & Fasilitas Transportasi & 726 & 5,80 \\
\hline & Pertahanan dan Keamanan & 43 & 0,34 \\
\hline & Industri & 74 & 0,59 \\
\hline & Pariwisata & 210 & 1,68 \\
\hline \multirow{8}{*}{ Non Terbangun } & Jumlah Te rbangun & 7.790 & 62,22 \\
\hline & Ruang Terbuka Hijau & 109 & 0,87 \\
\hline & Lapangan Olahraga & 31 & 0,25 \\
\hline & Hutan & 644 & 5,14 \\
\hline & Perairan & 241 & 1,92 \\
\hline & Persampahan & 47 & 0,38 \\
\hline & Pertanian & 3.659 & 29,22 \\
\hline & $\begin{array}{r}\text { Jumlah Non Te rbangun } \\
\Gamma \text { e rbangun }+ \text { Non Te rbangun) }\end{array}$ & $\begin{array}{r}4.731 \\
12.521\end{array}$ & $\begin{array}{r}37,78 \\
100,00\end{array}$ \\
\hline
\end{tabular}

Sumber: hasil analisis 2021 
Dilihat dari Tabel 6 jenis penggunaan lahan Kota Denpasar, penggunaan lahan yang sudah terbangun peruntukan berupa permukiman merupakan yang paling luas yaitu 5.771 ha atau sekitar 46,09\% dari 7.790 ha lahan Kota Denpasar yang terbangun, sedangkan untuk wilayah non terbangun, peruntukan lahan pertanian berupa sawah dan tegalan merupakan yang terluas dengan 3.659 ha atau sekitar 29,22\% dari total luas Kota Denpasar. Kemudian hutan mangrove yang terletak di kawasan pesisir Denpasar dengan luas 644 ha atau sekitar 5,14\% dari luasan Kota Denpasar (Gambar 3).

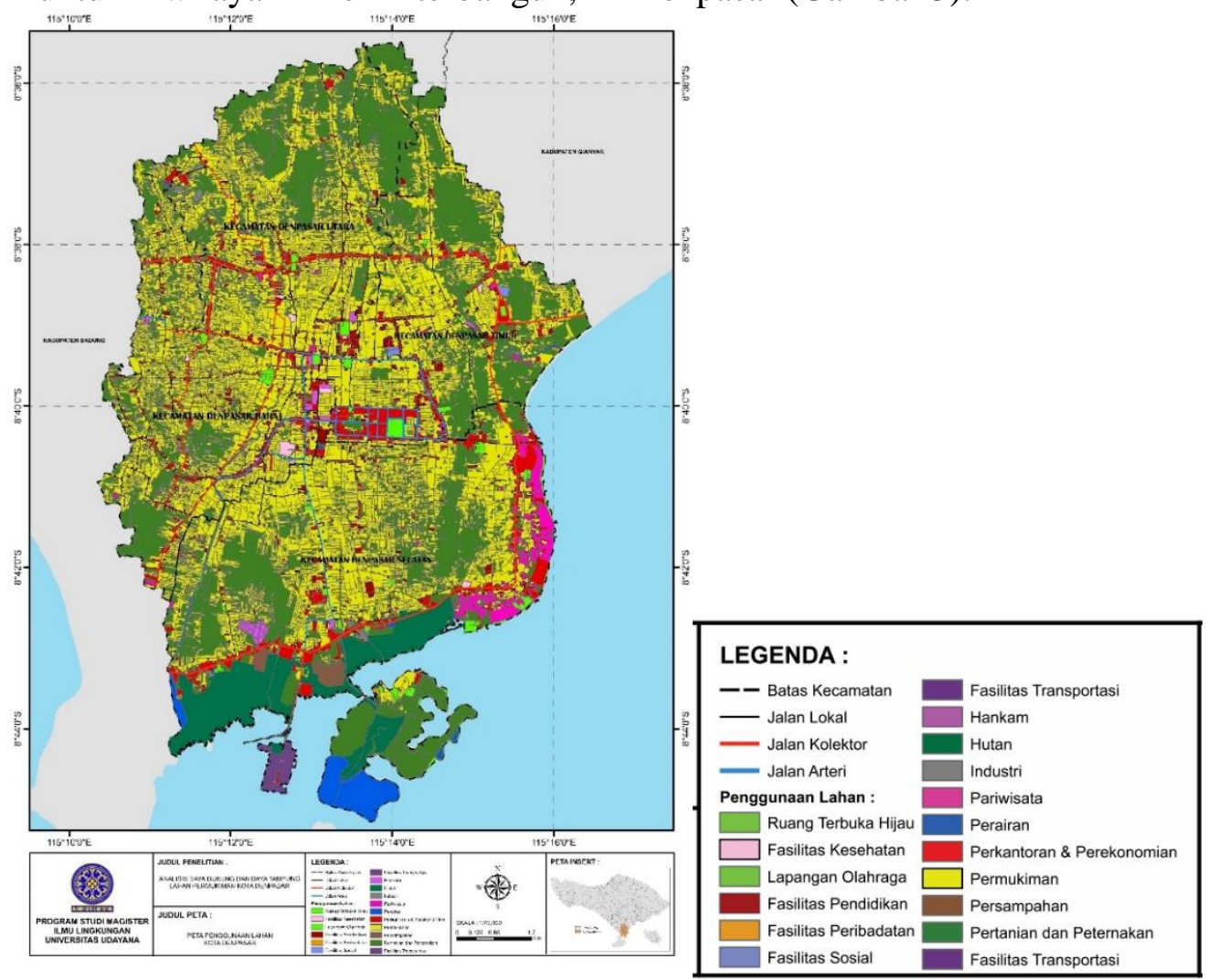

Gambar 3.

Peta Penggunaan Lahan Kota Denpasar Sumber: hasil olahan 2021

Dalam Peraturan Menteri Pekerjaan Umum Nomor 20 tahun 2007 tentang Teknik Analisis Aspek Fisik dan Lingkungan, Ekonomi serta Sosial Budaya dalam Penyususnan Renncana Tata Ruang dijelaskan teknik analisa fisik dan lingkungan, ekonomi serta sosial budaya, analisa kemampuan lahan yang didalamnya terdiri dari Satuan Kemampuan Lahan (SKL) dengan proses tumpang susun dan skoring sebagai analisa daya dukung. Hasil dari metode tumpang susun dan skoring SKL masih belum bisa digunakan untuk acuan penetapan lahan potensial, sedangkan Fansuri (2017) menyebutkan "berdasarkan kriteria Pusat Penelitian dan Pengembangan Geologi Bandung tentang kriteria peruntukan perumahan perkotaan yang sudah berfokus terhadap konstruksi bangunan sebagai pondasi perumahan" sehingga dapat dijadikan sebagai acuan dalam analisis daya dukung lahan permukiman Kota Denpasar.

Hasil dari dengan metode tumpang susun dan pemberian skor dari setiap variabel yang ada, sesuai dengan variabel daya dukung permukiman dengan menggunakan aplikasi GIS, total nilai atau skor dari masing-masing kawasan dapat diketahui dari bagan analisa, sehingga pengelompokan kawasan berdasarkan rentang skor, dengan skor yang terendah 24 dan skor yang tertinggi 96, dimana untuk menentukan interval kelas dapat dihitung dengan cara:

Interval Kelas $=$ (Nilai tertinggi - Nilai terendah) / Jumlah Kelas

Interval Kelas $=(96-24) / 3=24$

Dari hasil pencarian interval kelas kemampuan daya dukung, didapat:

- Kelas tidak leluasa dengan nilai $<48$,

- Kelas agak leluasa dengan nilai 48 - 73, dan

- $\quad$ Kelas leluasa dengan nilai $>73$

Untuk menghasilkan tingkat daya dukung lahan di Kota Denpasar, perhitungan ditentutan dari tumpang susun peta dari masingmasing kriteria yang telah diberikan skor. Gambar peta yang ditumpang susun dan diberi skor dapat dilihat pada Gambar 4. 


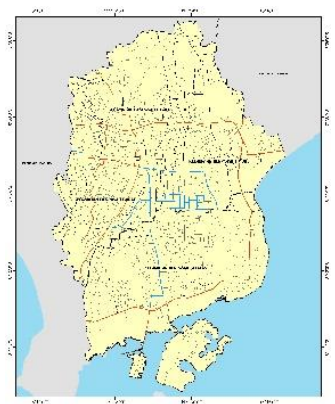

Kemiringan

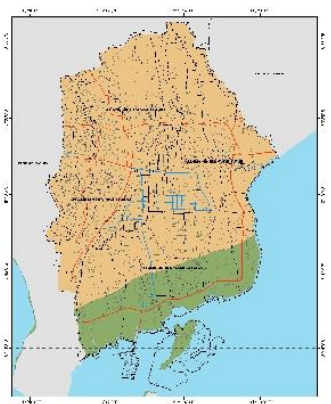

Jenis Batuan

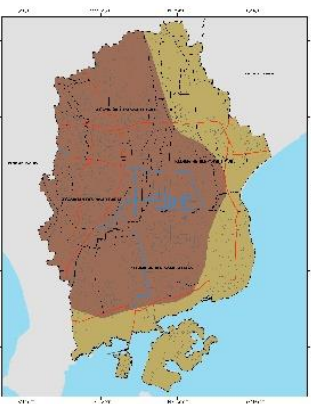

Jenis Tanah

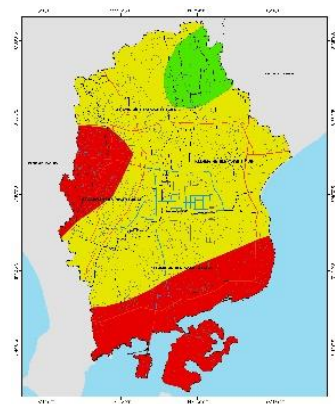

Pergerakan Tanah

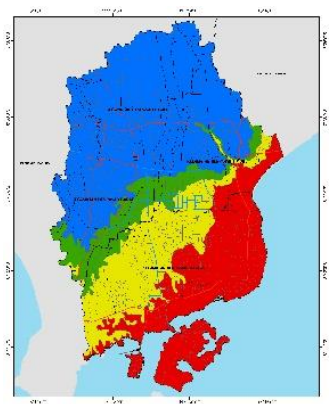

Rawan Tsunami

Gambar 4.

Tumpang Susun tiap variabel

Sumber: Hasil Olahan 2021

Berdasarkan analisis daya dukung lahan Kota Denpasar menggunakan aplikasi GIS, terdapat 3 kelas daya dukung lahan untuk pengembangan permukiman yaitu tidak leluasa, agak leluasa dan leluasa. Berikut Tabel kemampuan daya dukung lahan per Kecamatan di Kota Denpasar.

Tabel 7. Daya Dukung Lahan Kota Denpasar

\begin{tabular}{|c|c|c|c|c|c|}
\hline Tidak & $\begin{array}{l}\text { Daya } \\
\text { Leluasa }\end{array}$ & $\begin{array}{r}\text { Dukung } \\
\text { Agak }\end{array}$ & $\begin{array}{l}\text { Lahan (ha) } \\
\text { Leluasa }\end{array}$ & Leluasa & Total \\
\hline & 536 & & 2.603 & 1.768 & 4.907 \\
\hline & - & & 2 & $2.668^{\circ}$ & 2.670 \\
\hline & - & & 29 & 2.318 & 2.347 \\
\hline & - & & 143 & $2.454^{\top}$ & 2.597 \\
\hline & 536 & & 2.777 & 9.208 & 12.521 \\
\hline
\end{tabular}

Sumber : Analisis Tahun 2021

Dari hasil tumpang susun dan skoring, diperoleh daya dukung lahan Kota Denpasar lebih banyak merupakan kemampuan daya dukung kelas leluasa seluas 9.208 ha, dimana daerah tersebut mempunyai kemampuan yang bagus sebagai potensi pengembangan kawasan permukiman, Selain kelas leluasa, ada kelas agak leluasa sebesar 2.777 ha dimana kelas agak leluasa merupakan wilayah yang memiliki kemampuan yang cukup untuk dikembangkan sebagai kawasan permukiman. Kelas tidak leluasa juga terdapat sebesar 536 ha dimana kawasan tersebut tidak dianjurkan untuk kawasan pengembangan permukiman karena tidak mendukung keselamatan bangunan. Peta daya dukung lahan permukiman kota Denpasar dapat dilihat pada Gambar 5.

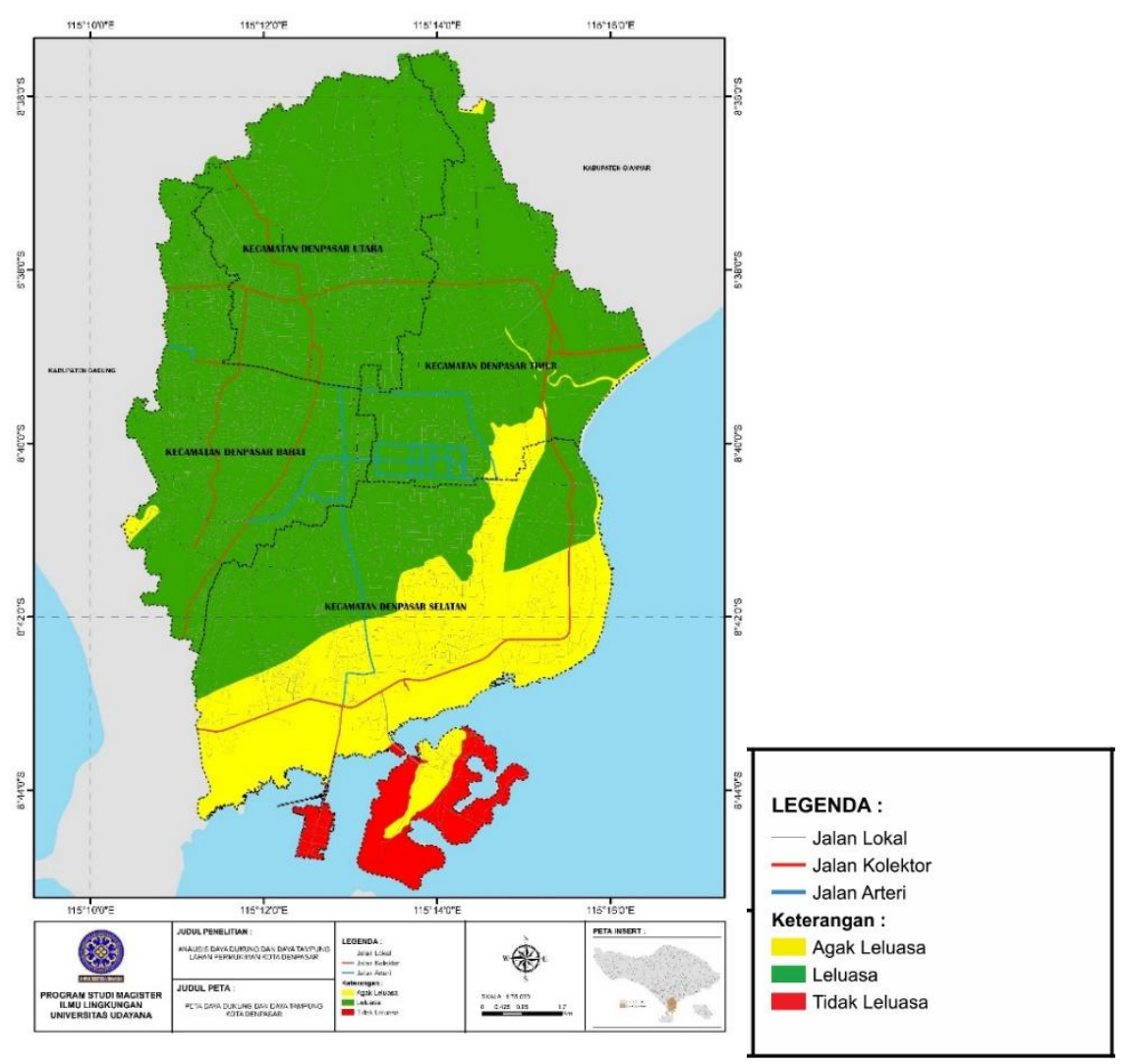

Gambar 5.

Peta Daya Dukung Lahan Kota Denpasar Sumber: hasil olahan 2021 
Dari perbandingan pemanfaatan lahan Kota Denpasar tiap kecamatan, terdapat wilayah yang tidak dapat dimanfaatkan untuk dikembangkan sebagai kawasan permukiman, seperti penggunaan lahan permukiman, fasilitas kesehatan, pendidikan, peribadatan, industri, kawasan pariwisata, fasilitas transportasi, pertahanan dan keamanan, fasilitas olah raga, dan perkantoran. Kawasan perairan meskipun merupakan kawasan yang belum dimanfaatkan, akan tetapi tidak dapat dikembangkan sebagai kawasan permukiman karena tidak dapat dan tidak layak untuk mendirikan pondasi. Kawasan yang belum termanfaatkan yang layak untuk dikembangkan untuk Kawasan permukiman antara lain pertanian dan area terbuka.

Berdasarkan perbandingan lahan potensial peruntukan permukiman, dapat diketahui jenis lahan yang leluasa untuk dikembangan sebagai kawasan permukiman antara lain adalah penggunaan lahan berupa area terbuka dan pertanian dan peternakan. Total jumlah lahan potensial yang dapat dikembangan sebagai lahan permukiman sebesar 2.920 ha (Tabel 8).

Tabel 8. Perbandingan Lahan Leluasa Peruntukan Permukiman

\begin{tabular}{|c|c|c|c|c|}
\hline Kecamatan & $\begin{array}{c}\text { Daya } \\
\text { Dukung }\end{array}$ & Pemanfaatan Lahan & $\begin{array}{c}\text { Penggunaan Lahan } \\
\text { Eksisting }\end{array}$ & $\begin{array}{c}\text { Total Luas } \\
\text { (ha) }\end{array}$ \\
\hline \multirow{4}{*}{$\begin{array}{l}\text { Denpasar } \\
\text { Selatan } \\
\text { Denpasar Utara }\end{array}$} & \multirow{2}{*}{ Leluasa } & \multirow{2}{*}{ Belum Termanfaatkan } & Area terbuka & \multirow{2}{*}{499} \\
\hline & & & Pertanian dan Peternakan & \\
\hline & \multirow{2}{*}{ Leluasa } & \multirow{2}{*}{ Belum Termanfaatkan } & Area terbuka & \multirow{2}{*}{964} \\
\hline & & & Pertanian dan Peternakan & \\
\hline \multirow[t]{2}{*}{ Denpasar Barat } & \multirow{2}{*}{ Leluasa } & \multirow{2}{*}{ Belum Termanfaatkan } & Area terbuka & \multirow{2}{*}{553} \\
\hline & & & Pertanian dan Peternakan & \\
\hline \multirow[t]{3}{*}{ Denpasar Timur } & \multirow{3}{*}{ Leluasa } & \multirow{3}{*}{ Belum Termanfaatkan } & Area terbuka & \multirow{2}{*}{904} \\
\hline & & & Pertanian dan Peternakan & \\
\hline & & & Jumlah & 2.920 \\
\hline
\end{tabular}

Sumber: Analisis tahun 2021

Setelah mendapatkan kawasan yang leluasa untuk dikembangkan untuk permukiman, kemudian akan ditumpang susunkan dengan rencana permukiman dalam Rencana Tata Ruang Wilayah Kota (RTRWK) Denpasar. Tumpang susun peta kawasan potensial pengembangan permukiman dengan rencana permukiman pada RTRWK Denpasar. Hasil dari proses dilakukan dengan tumpang susun peta lahan leluasa potensial pengembangan permukiman dengan peta rencana permukiman dalam RTRWK Denpasar menghasilkan peta kawasan potensial pengembangan permukiman Kota Denpasar.

Dalam overlay peta lahan leluasa pengembangan permukiman dengan rencana permukiman RTRW Kota Denpasar didapat luasan lahan potensial untuk dikembangkan sebagai kawasan permukiman di setiap kecamatan. Lahan potensial untuk pengembangan permukiman Kota Denpasar setelah dilakukan overlay dengan rencana permukiman RTRW Kota Denpasar dapat dilihat pada Tabel 9.
Tabel 9. Lahan Potensial Pengembangan Permukiman Kota Denpasar

\begin{tabular}{|c|c|c|c|}
\hline No & Kecamatan & $\begin{array}{c}\text { Luas Lahan } \\
\text { Leluasa (ha) }\end{array}$ & $\begin{array}{c}\text { Luas Lahan } \\
\text { Potensial } \\
\text { (ha) }\end{array}$ \\
\hline 1 & Denpasar Selatan & 499 & 106,92 \\
\hline 2 & Denpasar Utara & 964 & 165,82 \\
\hline 3 & Denpasar Barat & 553 & 164,45 \\
\hline 4 & Denpasar Timur & 904 & 212,42 \\
\hline \multicolumn{2}{|c|}{ Kota Denpasar } & $\mathbf{2 . 9 2 0}$ & $\mathbf{6 4 9 , 6 1}$ \\
\hline
\end{tabular}

Sumber : hasil olahan 2021

Dari Tabel 9 Lahan Potensial Pengembangan Permukiman Kota Denpasar diatas dilihat bahwa luas lahan potensial Kota Denpasar yang dapat dikembangkan untuk permukiman seluas 649,61 ha. Dari seluruh kecamatan di Kota Denpasar, Kecamatan Denpasar Timur memiliki lahan potensial pengembangan permukiman yang paling luas yaitu 212,42 ha, sedangkan Kecamatan Denpasar Selatan memiliki lahan potensial yang paling kecil yaitu sekitar 106,92 ha. 


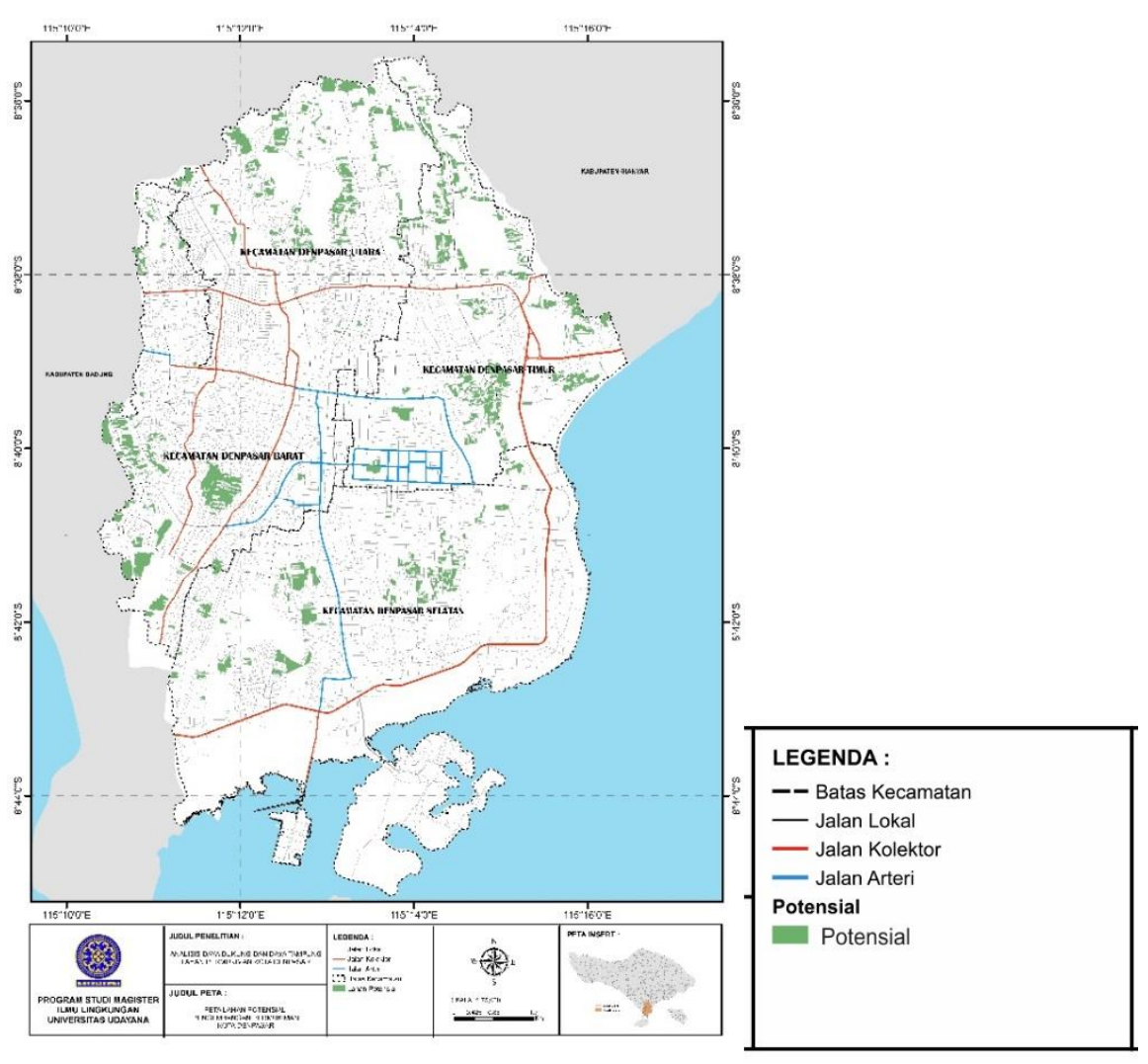

Gambar 6.

Peta Lahan Potensial Pengembangan Permukiman Kota Denpasar Sumber : hasil olahan 2021

\subsection{Daya Tampung Lahan Permukiman}

Penggunaan lahan peruntukan
perumahan sangat berkaitan dengan kemampuan daya tampung sebuah kawasan, dimana memperhitungkan kondisi persebaran kawasan perumahan dan arahan peran kawasan dalam rencana polar uang. Kemampuan daya tampung disini memperhatikan kebutuhan ruang untuk pengembangan perumahan dengan membandingkan lahan potensial. Asumsi penetapan daya tampung perumahan sebagai berikut:

Pasal 34 dalam dengan Undang-Undang Nomor 1 Tahun 2011 tentang Perumahan dan Kawasan Permukiman menyebutkan bahwa hunian berimbang harus wajib diterapkan dalam perencanaan pengembangan perumahan. Maka tipe rumah sederhana, tipe rumah menengah dan tipe rumah mewah harus tetap dimasukan dalam perencanaan pengembangan perumahan. Perbandingan tipe rumah berdasarkan ketentuan hunian berimbang antara kavling sederhana: menengah: mewah adalah 3:2:1. Luasan kavling untuk rumah sederhana adalah 60-200 $\mathrm{m}^{2}$ berdasarkan Peraturan Menteri Perumahan Rakyat Nomor 10 Tahun 2010. Kebutuhan Luas Minimum Bangunan dan Lahan untuk Rumah Sederhana dapat dilihat pada Tabel 10, sedangkan Daya Tampung Rumah dan Daya Tampung Penduduk di Kota Denpasar dapat dilihat pada Tabel 11.
Tabel 10. Kebutuhan Luas Minimum Bangunan dan Lahan untuk Rumah Sederhana

\begin{tabular}{lcccc|c}
\hline \multirow{2}{*}{$\begin{array}{c}\text { Standar Per } \\
\text { Jiwa }\left(\mathbf{m}^{2}\right)\end{array}$} & \multicolumn{4}{c}{ Luas $\left(\mathbf{m}^{2}\right)$ untuk 4 jiwa } \\
\cline { 2 - 5 } & Unit Rumah & \multicolumn{3}{c}{ Lahan } \\
\cline { 2 - 5 } & Minimal & Efektif Ideal \\
\hline (Ambang Batas) 7 & 28,8 & 60 & $72-90$ & 200 \\
\hline (Indonesia) 9,0 & 36 & 60 & $72-90$ & 200 \\
\hline (Internasional) 12 & 48 & 70 & - & - \\
\hline
\end{tabular}

Sumber: Fansuri, 2017

Dari ketentuan kebutuhan luas minimal bangunan dan lahan untuk rumah sederhana diatas, maka perkiraan tipe rumah adalah:

- Kavling Rumah Sederhana seluas $72 \mathrm{~m}^{2}$ (diambil dari nilai efektif minimum 72 $90 \mathrm{~m}^{2}$ ).

- Kavling Rumah Menengah seluas 144 $\mathrm{m}^{2}$ (diambil dari kelipatan 2 nilai kavling rumah sederhana)

- Kavling Rumah Mewah seluas288 m² $^{2}$ (diambil dari kelipatan 4 nilai kavling rumah sederhana)

- Perkiraan penghuni rumah diasumsikan 4 orang

Berdasarkan analisis daya tampung lahan perumahan, diketahui luas lahan yang layak untuk perumahan sebesar 454,73 ha dan sebanyak 44.736 unit rumah yang dapat ditampung yang terdiri dari 2.632 unit tipe rumah mewah, 10.526 unit tipe rumah menengah, 31.578 unit tipe rumah sederhana dan menampung sebesar 178.943 jiwa penduduk. Lebih jelas perbandingan daya tampung penduduk Kota Denpasar tahun 2030 dapat dilihat pada Tabel 12. 
Tabel 11. Daya Tampung Rumah dan Daya Tampung Penduduk di Kota Denpasar

\begin{tabular}{|c|c|c|c|c|c|c|c|c|c|c|c|}
\hline \multirow{3}{*}{ Kecamatan } & \multirow{2}{*}{$\begin{array}{l}\text { Kesesuaian } \\
\text { Lahan } \\
\text { Permukiman } \\
\text { (ha) }\end{array}$} & \multirow[b]{2}{*}{$\begin{array}{c}\text { PSU } \\
(30 \%)\end{array}$} & \multirow[b]{2}{*}{$\begin{array}{c}\text { Perumahan } \\
(70 \%)\end{array}$} & \multicolumn{3}{|c|}{ Luas Lahan Perumahan } & \multicolumn{3}{|c|}{ Jumlah Rumah } & \multirow{2}{*}{$\begin{array}{c}\text { Daya } \\
\text { Tampung } \\
\text { Rumah } \\
\text { (Unit) }\end{array}$} & \multirow{2}{*}{$\begin{array}{c}\text { Daya } \\
\text { Tampung } \\
\text { Penduduk } \\
\text { (Jiwa) }\end{array}$} \\
\hline & & & & $\begin{array}{c}\text { Tipe } \\
\text { Mewah }\end{array}$ & $\begin{array}{c}\text { Tipe } \\
\text { Menengah }\end{array}$ & $\begin{array}{c}\text { Tipe } \\
\text { Sederhana }\end{array}$ & $\begin{array}{c}\text { Tipe } \\
\text { Mewah }\end{array}$ & $\begin{array}{c}\text { Tipe } \\
\text { Menengah }\end{array}$ & $\begin{array}{c}\text { Tipe } \\
\text { Sederhana }\end{array}$ & & \\
\hline & $\mathbf{A}$ & $B=[\mathbf{A x 3 0} \%]$ & $\mathrm{C}=[\mathrm{Ax} \mathbf{7 0} \%]$ & $D=[C \times 1 / 6]$ & $\mathrm{E}=[\mathrm{Cx} 2 / 6]$ & $\mathrm{F}=[\mathrm{Cx} 3 / 6]$ & $\begin{array}{r}\mathrm{G}=[\mathrm{Dx} 10.00 \\
\left.0 \mathrm{~m} / \mathbf{2 8 8} \mathrm{m}^{2}\right]\end{array}$ & $\begin{array}{c}\mathrm{H}=[\mathrm{Ex} 10.000 \\
\left.\mathbf{m} / \mathbf{1 4 4 m ^ { 2 }}\right]\end{array}$ & $\begin{array}{c}\mathbf{I}=\mathbf{F x 1 0 . 0 0 0} \\
\left.\mathbf{m} / 72 \mathrm{~m}^{2}\right]\end{array}$ & $\mathbf{J}=\mathbf{G}+\mathbf{H}+\mathbf{I}$ & $\mathrm{K}=\mathbf{J} \mathbf{x} 4 \mathrm{Jiwa}$ \\
\hline $\begin{array}{l}\text { Denpasar } \\
\text { Selatan }\end{array}$ & 106,92 & 32,08 & 74,84 & 12,47 & 24,95 & 37,42 & 433 & 1.733 & 5.198 & 7.363 & 29.453 \\
\hline $\begin{array}{l}\text { Denpasar } \\
\text { Utara }\end{array}$ & 165,82 & 49,75 & 116,07 & 19,35 & 38,69 & 58,04 & 672 & 2.687 & 8.061 & 11.419 & 45.677 \\
\hline $\begin{array}{l}\text { Denpasar } \\
\text { Barat }\end{array}$ & 164,45 & 49,34 & 115,12 & 19,19 & 38,37 & 57,56 & 666 & 2.665 & 7.994 & 11.325 & 45.300 \\
\hline $\begin{array}{l}\text { Denpasar } \\
\text { Timur }\end{array}$ & 212,42 & 63,73 & 148,69 & 24,78 & 49,56 & 74,35 & 860 & 3.442 & 10.326 & 14.628 & 58.514 \\
\hline Jumlah & 649,61 & 194,88 & 454,73 & 75,79 & 151,58 & 227 & 2.632 & 10.526 & 31.578 & 44.736 & 178.943 \\
\hline
\end{tabular}

Sumber: Analisis tahun 2021

Berdasarkan Tabel 12 diketahui lahan potensial pengembangan perumahan Kota Denpasar seluas 454,72 ha mampu menampung sekitar 178,944 penduduk. Dari 4 kecamatan, ada 2 kecamatan yang tidak mampu menampung perkembangan penduduk pada tahun 2030 yaitu Kecamatan Denpasar Selatan dan Denpasar Utara. Pada Kecamatan Denpasar Selatan, luas lahan potensial pengembangan permukiman defisit 42.316 jiwa yang tidak bisa ditampung pada tahun 2030. Begitu juga Kecamatan Denpasar Utara yang defisit 3.180 jiwa tidak bisa ditampung pada tahun 2030. Sedangkan Kecamatan Denpasar Barat dan Denpasar Timur masih mampu menampung jumlah penduduk pada tahun 2030. Dengan proyeksi jumlah penduduk dari akumulasi setiap kecamatan total sekitar 1.169.669 jiwa pada tahun 2030, surplus sekitar 15.372 jiwa yang masih mampu ditampung oleh lahan Kota Denpasar untuk pengembangan perumahan. Hal tersebut mengindikasikan bahwa kemampuan daya tampung lahan permukiman Kota Denpasar masih mencukupi untuk menampung pertumbuhan penduduk pada tahun 2030, meskipun tidak semua kecamatan mampu menampung perkembangan penduduknya. Kemampuan daya tampung penduduk Kota Denpasar merupakan kumulatif dari semua kecamatan dimana total dari luas kemampuan daya dukung disandingkan dengan total jumlah proyeksi penduduk pada tahun 2030 yang kemudian dijadikan acuan penetapan daya tampung lahan permukiman Kota Denpasar.

Tabel 12. Perbandingan Daya Tampung Penduduk Tahun 2030

\begin{tabular}{|c|c|c|c|c|c|c|}
\hline Kecamatan & 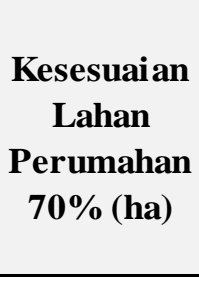 & $\begin{array}{c}\text { Daya } \\
\text { Tampung } \\
\text { Penduduk } \\
\text { (Jiwa) }\end{array}$ & $\begin{array}{l}\text { Proyeksi } \\
\text { Penduduk } \\
\text { Tahun } \\
2030 \\
\text { (Jiwa) }\end{array}$ & $\begin{array}{c}\text { Selisih } \\
\text { Jumlah } \\
\text { Penduduk } \\
\text { Tahun 2019 } \\
\text { dengan 2030 } \\
\text { (Jiwa) } \\
\end{array}$ & $\begin{array}{c}\text { Perbandingan } \\
\text { Daya Tampung } \\
\text { dengan Selisih } \\
\text { Jumlah } \\
\text { Penduduk }\end{array}$ & Keterangan \\
\hline Denpasar Selatan & 74,84 & 29.453 & 377.169 & 71.769 & -42.316 & $\begin{array}{c}\text { Tidak } \\
\text { Mencukupi }\end{array}$ \\
\hline Denpasar Utara & 116,074 & 45.677 & 256.757 & 48.857 & -3.180 & $\begin{array}{c}\text { Tidak } \\
\text { Mencukupi }\end{array}$ \\
\hline Denpasar Barat & 115,115 & 45.300 & 337.896 & 27.086 & 18.214 & Mencukupi \\
\hline Denpasar Timur & 148,694 & 58.514 & 197.847 & 15.860 & 42.654 & Mencukupi \\
\hline Jumlah & 454,72 & 178.944 & 1.169 .669 & 163.572 & 15.372 & Mencukupi \\
\hline
\end{tabular}

Sumber : Analisis Tahun 2021

\section{SIMPULAN}

Dari hasil dan pembahasan yang sudah dilakukan, disimpulkan bahwa kemampuan daya dukung lahan Kota Denpasar yang memiliki kelas leluasa untuk dikembangan sebagai kawasan permukiman seluas 9.028 ha tersebar di seluruh kecamatan. Lahan potensial Kota Denpasar untuk dikembangan sebagai Kawasan permukiman tersedia sebesar 454,73 ha dari total luas Kota Denpasar sebesar 12.521 ha atau sekitar 3,63\% lahan di Kota Denpasar merupakan lahan potensial.

Daya tampung rumah maksimal di Kota Denpasar dengan luas lahan potensial perumahan sebesar 454,73 yang merupakan $70 \%$ dari kesesuaian lahan perumahan seluas 649,61 ha, dan mampu menampung sekitar 44.736 unit rumah dan 178.943 jiwa penduduk. Ada 2 Kecamatan yang tidak mampu menampung penduduk pada tahun 2030 yaitu Kecamatan Denpasar Selatan dan Denpasar Utara. Akan tetapi secara kumulatif, Kota Denpasar masih mampu menampung 
pertumbuhan penduduk pada tahun 2030 dalam mendapatkan lahan hunian.

\section{DAFTAR PUSTAKA}

Badan Pusat Statistik (2010). Pedoman Penghitungan Proyeksi Penduduk dan Angkatan Kerja, Badan Pusat Statistik : Jakarta.

Ernamaiyanti \& Yunanda, Mega (2019). Analisis Daya Dukung dan Daya Tampung Lahan Pengembangan Perumahan Dan Pemukiman Provinsi Banten. Jurnal Teknik Sipil UNPAL Vol 9, No 1

Damanik, F.P., Haryani \& Aditia, E. (2018). Penentuan Lahan Potensial dalam Pengembangan Lahan Permukiman Berbasis GIS di Kota Solok, Padang : Universitas Bung Hatta.

Fansuri, F.(2017). Analisa Daya Dukung dan Daya Tampung Lahan Perumahan (Studi Kasus Kecamatan Cimahi), Bandung: Universitas Pasundan.

Kuswara. (2012). Daya Dukung Lahan Untuk Pengembangan Perumahan Di Pulau Panggang, Pulau Pramuka, Pulau Kelapa dan Pulau Tunda. Balai Pengembangan Teknologi Perumahan Tradisional Makassar Pusat Litbang Permukiman, Badan Litbang Kementerian Pekerjaan Umum

Maria, Runtukahu P., Sangkertadi \& Supardjo, S. (2018). Analisis Daya Dukung Dan Daya Tampung Lahan Di Kecamatan Malalayang Kota Manado. Media Matrasain Volume 15, No.2 : Universitas Sam Ratulangi Manado

Muta'ali, Lutfi. (2012). Daya Dukung Lingkungan Untuk Perencanaan Pengembangan Wilayah. Yogyakarta : Badan Penerbit Fakultas Geografi (BPFG) Universitas Gadjah Mada

Muta'ali, Lutfi. (2015). Teknik Analisis Regional Untuk Perencanaan Wilayah Tata Ruang dan Lingkungan. Yogyakarta: Badan Penerbit Fakultas Geografi (BPFG).
Pantow, M., Moniaga, I. \& Takumsang ,E. (2018). Daya Dukung Permukiman Dalam Konsep Pengembangan Wilayah Di Kecamatan Langowan Timur. Jurnal Spasial Vol 5. No. 3, 2018

Ridha, R., Utari Vipriyanti, Nyoman \& Wiswasta, IGN Alit (2016). Analisis Daya Dukung Lahan Sebagai Pengembangan Fasilitas Perkotaan Kecamatan Mpunda Kota Bima Tahun 2015 - 2035. Denpasar : Universitas Mahasarawati.

Sadana, Agus. (2014). Perencanaan Kawasan Permukiman. Yogyakarta: Graha Ilmu.

Sugiyono.(2016). Metode Penelitian Kuantitatif, Kualitatif dan R\&D. Bandung: PT Alfabet.

Suharto, B., Rahadi, B., \& Sofyansah, Ari (2015). Evaluasi Daya Dukung Dan Daya Tampung Ruang Permukiman Di Kota Kediri. Jurnal Sumberdaya Alam dan Lingkungan

Undang-Undang Republik Indonesia Nomor 1 Tahun 2011 Tentang Perumahan dan Kawasan Permukiman.

Peraturan Daerah Kota Denpasar Nomor 27 Tahun 2011 Tentang Rencana Tata Ruang Wilayah Kota Denpasar 20112031.

Peraturan Daerah Provinsi Bali Nomor 5 Tahun 2005 tentang Persyaratan Bangunan Gedung.

Wesnawa. (2015). Geografi Permukiman, Yoyakarta: Graha Ilmu

Widiastuti, A. S., Maretya, D. A., Wangge, G. A., Suci, A., Nurkholis, A., Widyaningsih, Y., Rahma, A. D., Abdillah, A. 2016. Daya Dukung Lahan Pertanian, Permukiman, dan Kawasan Lindung di DAS Sembung, Kabupaten Sleman, DIY : Universitas Gadjah Mada

Wiryananda, N.G.A.K, Hasibuan, H.S \& Madiasworo, T. 2018. Kajian Pemanfaatan Ruang Kota Berkelanjutan (Studi kasus Kota Denpasar). Jakarta: Universitas Indonesia 